\title{
Social media capital and civic engagement: Does type of connection matter?
}

\author{
Young-joo Lee ${ }^{1}$ (1)
}

Received: 29 March 2021 / Accepted: 1 June 2021 / Published online: 2 July 2021

(c) The Author(s), under exclusive licence to Springer-Verlag GmbH Germany, part of Springer Nature 2021

\begin{abstract}
This study examines the relationship between a person's social media capital and civic engagement, focusing on the networks formed via two social network sites (SNSs) of Facebook and Twitter. The analysis of the survey data on young people's social media use and civic engagement in the U.S. shows that, although all three types of online social ties (Facebook Friends, Twitter followers, and people one follows on Twitter) are positively associated with civic engagement, there are differences across the different types of connections. The findings reveal that Twitter social capital is more strongly associated with participation in political organizations while Facebook social capital is more strongly associated with participation in non-political charitable organizations. Between Twitter followers and following, the number of people one follows is more strongly associated with participation in both types of organizations than the number of one's followers. These findings suggest that nonprofit managers take a platform-specific approach when using social media for marketing and stakeholder involvement.
\end{abstract}

Keywords Social Media Capital · Social Network Sites · Civic Engagement · Facebook · Twitter

Social capital plays an important role in eliciting prosocial behaviors and civic engagement (Brown \& Ferris, 2007). Civic engagement refers to a variety of ways in which people participate in the life of a community to improve conditions for other members (Adler \& Goggin, 2005). The literature suggests that social capital makes it easier for individuals to link their own identities and interests with those of the community, and therefore helps them overcome the dilemma of collective action (Glanville et al., 2016; Wilson \& Musick, 1998). This, in turn, facilitates people's participation in civic engagement activities. Empirical research supports this

Young-joo Lee

Young-Joo.Lee@ucf.edu

1 School of Public Administration, University of Central Florida, 528 W Livingston Street,

Orlando, FL 32802, USA 
perspective by showing that a person's stock of social capital is positively associated with the level of charitable giving, volunteering and other types of civic engagement (Brown \& Ferris, 2007; Lee \& Brudney, 2012). Wilson \& Musick (1998) suggest that the differences in extensive social ties and networks are what sets those who participate in civic engagement apart from those who do not participate.

Although the connection between social capital and civic engagement is wellestablished and widely accepted, there still exist debates regarding whether this connection applies to the case of online social capital, which derives from a person's connections formed via Internet. Research suggests that online social capital is a special form of social capital, with a distinctive characteristics and outcomes that set it apart from traditional social capital formed via in-person interactions (de Zúñiga et al., 2017; Saxton \& Guo, 2020). De Zúñiga and colleagues (2017) suggest that social media capital differs from traditional social capital in terms of the types of social values and resources derived from the network, the process of developing values in social relationships, as well as how these values and resources are converted into social or political action. Despite the ever-growing importance of online social capital and its unique features, little is known as to whether online social capital has similar civic engagement implications and what these implications mean for nonprofit organizations and their marketing and communication strategies.

There exist two contrasting perspectives on online social capital's civic engagement implications. Those who hold a skeptical view on online social capital's civic engagement implication emphasize that young people's empathy for others, civic engagement, and political involvement have declined as social media have become popular (Twenge, 2013). Twenge's (2013) study of millennials' social media use reports that the influence of a person's social capital formed via social network sites (SNSs) is limited to low-effort online engagement behaviors and it does not affect one's high-effort engagement behaviors. Research suggests that interactions via Internet supplement or replace face-to-face exchanges, and consequently, diminish offline social interactions (Bargh \& McKenna, 2004; Johnston et al., 2013). Diminished social interactions, in turn, negatively affect a person's civic engagement. Studies also show that various SNS usage stats, including frequency of updates/ tweets and number of friends/followers, are positively associated with loneliness, depression and narcissism, which hamper a person's prosocial motivations (Lin et al., 2016; McCain and Campbell, 2018). Overall, this line of research suggests that online social networks have little, if not adverse, influence on offline social connectedness and social integration and they have a potential to undermine the culture of civic engagement (Clark et al., 2018).

Despite the skepticism, recent empirical studies find that the virtual social capital built via social media platforms, social media capital henceforward, is positively associated with young people's civic engagement (Lee, 2020; You \& Hon, 2019). Scholars focus on the creation and maintenance of social capital via SNSs, as these platforms have the capacity to reshape social networks and lower the costs of establishing and managing the networks (Ellison et al., 2010; Johnston et al., 2013). The development of information technology has increased the efficiency of person-toperson connections and removed geographical barriers, and SNSs have become common tools for establishing and maintaining connections with others (Ellison 
et al., 2007). As such, research suggests that SNSs are effective in connecting individuals and organizations and generating civic engagement.

The increasing importance of SNSs in social capital creation and the mixed findings about the role of virtual social capital in civic engagement make better understanding social media capital's behavioral implications a timely and important research topic. Moreover, civic engagement plays a vital role in nonprofits' sustainability (Matos \& Fernandes, 2021), and therefore, understanding the social media capital-civic engagement relationship will offer critical implications for nonprofit communication and marketing strategies. This study examines the relationship between young people's social media capital and their participation in civic engagement activities, focusing on the two SNSs of Facebook and Twitter. In particular, this study tests how the three different types of connections-Facebook friends, Twitter followers, and people a user follows on Twitter-predict the participation in civic engagement via two different types of organizations: political organizations and non-political charitable organizations. The subsequent section provides a review of the literature on social media capital and its civic engagement implications.

\section{Social medica capital and civic engagement}

Bourdieu (1986, p. 248) defined social capital as "the aggregate of the actual or potential resources which are linked to possession of a durable network of more or less institutionalized relationships of mutual acquaintances and recognition." This definition implies that a person's social capital lies in the structure of relationships within which one is located, and the stock of social capital is determined by the connections one has (Johnston et al., 2013; Portes, 1998). Hence, like other forms of capital, such as financial capital and human capital, a person's social capital can be quantitatively measured with his or her stock of relationships (Ellison et al., 2010). The literature also suggests that social capital as resources accumulated from various relationships has various behavioral implications (Coleman, 1988). Most importantly, trust and social ties in networks with other individuals generate the 'virtuous circle' of social capital that can create the context for collective action for social problems (Warren et al., 2015).

SNSs have the unique ability to transmit information and build relationships among large groups of individuals, regardless of geographical locations and without significant monetary costs (Pasek et al., 2009). Moreover, with the development of information technology and infrastructure, people can easily access their online social connections at anytime and anywhere using their networked mobile devices. SNSs also allow individuals to relate in new ways, and the importance of these platforms in creating and maintaining social capital has increased significantly (Phua et al., 2017). These platforms have not only increased the resources that individuals and organizations are able to mobilize for developing and adopting socially innovative practices, but the nature of social connectedness has also evolved as a result of the widespread use of SNSs (Mosconi et al., 2017). The importance of SNSs in social capital creation is especially prominent among millennials, as they have spent their entire lives in digital environment and are major users of these sites (Lee, 
2020). Research suggests that SNSs and other social media platforms have been utilized as an important vehicle for millennial participation and volunteering, offering dialogical communication that bypasses traditional mass media filters and facilitating mobilization of individuals (De Zúñiga et al., 2017; Kaun \& Uldam, 2018).

The growing importance of SNSs in people's lives and the unique qualities of social media capital created in these platforms have led to a question whether social media capital has the same behavioral implications from traditional off-line social capital, especially in terms of people's civic engagement and participation (De Zúñiga et al., 2017). The answer to the question of social media capital's civic participation implications is divided into two opposing perspectives: the first emphasizes the loose connections formed in SNSs and the lack of their offline behavioral implication; in opposition, the second focuses on the strength of virtual social ties and their impact on civic engagement.

The first perspective emphasizing social media capital's limited real-world implications explains that SNS users establish connections with others and navigate these connections exclusively in the virtual space, seeking platform-specific social support and affiliation (De Zúñiga et al, 2017). This perspective posits that virtual communities are pseudo communities and social capital from these communities have little real-world implication (Gavrilutăă \& Bortoş, 2020; Harasim, 1993). Research suggests that online connections tend to be latent and weak, compared with the social ties formed via offline face-to-face platforms, and therefore the influence of social ties formed through SNSs is limited to the users' online behaviors (de Zúñiga \& Valenzuela, 2011). According to this view, social medial capital has disparate behavioral implications from the consequences of social capital created in offline settings (Ellison et al., 2011; Saxton \& Guo, 2020). Scholars who hold this view describe young people's online social action as "slacktivism" or "clicktivism," arguing that online social engagement satisfies young people's moral and psychological needs for community engagement, thereby excusing them from participating in other forms of civic participation which typically requires higher levels of efforts (Lane \& Cin, 2018). These scholars argue that low-cost online engagement activities, such as signing petitions or joining Facebook groups, are token displays of support and impression management behaviors, which accompany lack of willingness to devote significant effort to other meaningful engagement behaviors beyond the virtual world (Kristofferson et al., 2014). According to their view, a nonprofit's virtual communities are pseudo communities and expanding these pseudo communities have little practical implication for organizational outcomes and mission achievement (Gavrilutăă \& Bortoş, 2020; Harasim, 1993).

In contrast, researchers who focus on the strengths of virtual social ties emphasize that virtual communities are typically formed based on shared interests, goals, needs or practices, and therefore, social capital developed from such communities is strong enough to stimulate individuals to reach beyond the virtual world (Chiu et al., 2006; Warren et al., 2015). They suggest that the novel ways of engagement in SNSs provide their users with new opportunities to engage in various social and community activities. Individuals typically use SNSs for such reasons as identifying with others, gaining sense of belonging, and finding a basis for social interaction, which are the same reasons as why people establish connections with others offline (Valenzuela 
et al., 2009). Scholars also suggest intertwinement between social media capital and offline social capital, explaining that social connections formed offline translating to online connections, or vice versa (Boyd \& Ellison, 2007; Ramirez et al., 2017).

Recent research on nonprofit organizations' social media use suggests that the relationships built in online communities of a nonprofit organization contribute to an increased sense of community beyond social media (Vossen \& Valkenburg, 2016). Therefore, individuals who are engaged in a nonprofit organization's online communities are more likely to participate in activities benefitting the organization and its mission (Clark \& Melancon, 2013). In this sense, the implications of a nonprofit's online social capital go beyond the online community and are effective in generating support behaviors for the organization. Studies also find that online social interactions are positively associated with common indicators of social capital, such as generalized social trust, suggesting the similarities between social media capital and traditional social capital (Best \& Krueger, 2006). Hence, using SNSs for a socialization purpose results in individual-level production of social capital, whose implication goes beyond the virtual space (Valenzuela et al., 2009). In sum, this approach postulates that one's social media capital has the same positive implications for collective action, including civic engagement and participation, as traditional off-line social capital (Mandarano et al., 2010; You \& Hon, 2019).

The conflicting views on social media capital become more complicated by the distinctive nature of social connectedness in each platform. Research suggests that social media platforms are structurally different from one another, with regard to how relationships are established and made visible (Boyd \& Ellison, 2007). Each platform also offers its users a unique communication experience in a site-specific culture, and such differences suggest that understanding the social medica capital's implication for civic engagement requires consideration of the platform-specific context (Errasti et al., 2017; Hughes et al., 2012; Pasek et al., 2009). This study examines how three different of types of SNS social ties-Facebook friends, Twitter followers and Twitter following - are associated with a person's civic engagement. The following section discusses the unique characteristics of each type.

\subsection{Social ties on facebook}

Facebook users connect with other users by "friending." Becoming Facebook friends means that users can see the friends' activity in news feed, stories and photos on their accounts. On Facebook, a user can send a friend request to other users, and the ones who receive a request choose whether or not to accept it. When a friend request is accepted, the user automatically joins the requester's network (Davenport et al., 2014). Therefore, a person's friend network size is mostly under one's control. Due to this mutuality of shared networks, the group interaction available on Facebook also helps users build trusting and reciprocal relationship with other users, which in turn, fosters opportunities to motivate people in collective action (You \& Hon, 2019).

These reciprocal connections with one's Facebook "friends" resemble the offline social ties and have similar behavioral consequences as do offline social networks 
(Ellison et al., 2007; Mayer \& Puller, 2008; Phua et al., 2017). In fact, scholars explain that the reciprocal nature of Facebook networks has contributed to Facebook's being most frequently studied SNS in the social media-civic engagement literature (Valenzuela et al., 2009). Empirical studies also offer an array of examples and prospects of how Facebook has become the nexus of civic involvement addressing community challenges and proceeding to take action to resolve these challenges (Warren et al., 2015). Research reports that Facebook is used to mobilize an online movement, which often leads to an offline social movement. For instance, studies show that Facebook users are more politically engaged than non-users in various ways, including voting, participating in a rally, and encouraging others to vote (Conroy et al., 2012; Hampton et al., 2012; Harlow, 2012).

\subsection{Social ties on twitter}

Unlike Facebook, Twitter does not provide an option to "friend" people, and one can only follow other users and be followed by others. In fact, Twitter is classified as a micro-blogging site, as well as a social network site, due to its low level of reciprocal connections and the platform's focus on information sharing (Shane-Simpson et al., 2018). Studies reveal that Twitter is used primarily for one-way interactions where users "tweet" information to their social ties, called "followers." The term "followers" describes a user's audience, whereas the term "following" refers to a user's subscription to other users' accounts (Hofer \& Aubert, 2013). The two terms of "followers" and "following" also imply a unidirectional relationship, compared with a more egalitarian term of "friends" in Facebook (Davenport et al., 2014). Social ties formed by following require a user neither to accept requests for connection nor to become a follower of those who follow them. Hence, Twitter users can only control the number of people they follow, and they have no control over the number of people who follow them.

Because Twitter users do not need an approval to follow other users, people can connect with others more easily on Twitter than on Facebook (Hofer \& Aubert, 2013). This suggests that, compared with Facebook and other SNSs, Twitter users are more likely to connect with the people they do not have a real-life relationship, such individuals as celebrities and politicians (Phua et al., 2017). As a result, Twitter offers more flexible opportunities to connect with loose ties, and these "diverse and loosely-linked connections" characterize social ties on Twitter (Phua et al., 2017, p.119; Shane-Simpson et al., 2018).

The unidirectional nature of the Twitter relationships also suggests that the difference between the two types of connections- "following" and "follower"-be taken into consideration in discussing the nature of social capital created in Twitter. Research reports that Twitter users consider their followers as a community of likeminded individuals whose similarities make connection easier. On the other hand, Twitter users follow other users who are from a more heterogenous group in order to receive information that was not previously available to them so that they could feel like a part of a broader group (Hofer \& Aubert, 2013). Such differences in the nature 
of "follower" and "following" relationships imply that the two types of connections have dissimilar behavioral implications.

In summary, social ties formed in different platforms may have distinctive characteristics, and therefore the behavioral implications of social media capital can vary across platforms. Facebook relationships tend to be more reciprocal and to resemble offline social relationships, when compared with the social ties formed on Twitter (Davenport et al., 2014). The connections on Twitter are characterized by more diverse and loosely linked ties and tend to be more unidirectional. The differences in the nature of social ties between the two platforms suggest that studies of social media capital's behavioral implications account for site-specific social media capital. Existing research, however, tends to focus on a single platform, mostly on Facebook, and little attention has been given to whether social connectedness in different social media platforms has the same civic engagement implications. In addition to the variations across platforms, the difference between "follower" and "following" relationships require distinguishing the two types of connections when studying their behavioral implications. In this study, the relationship between social media capital and civic engagement is examined using three different measures of social media capital: 1) a person's Facebook friends, 2) Twitter followers, and 3) following on Twitter. This study also investigates the social media capital-civic engagement link in two different contexts of civic engagement: participation in political organizations and non-political charitable organizations. This study tests whether the social media capital relationship takes different forms across the three types of the social ties and under the two organizational contexts.

\section{Data and methods}

This study uses the data from The Civic Network: A Comparative Study of the Use of Social Media for Enhancing Young People's Political Engagement, Australia, United Kingdom, \& United States, 2013 (ICPSR 37,023), which was designed and implemented by Ariadne Vromen and her colleagues. According to the study, young people (ages from 16 to 29) were recruited from online panels to create samples that mirrored each country's census data, which added up to a total of 3,887 individuals participating in the web-based survey. Because the context of civic engagement and participation differs significantly across countries (Schofer \& Fourcade-Gourinchas, 2001), this study limits its focus on American youth. The U.S. data were collected between March 22 and April 16, 2013, and there were 1,224 observations in total.

\subsection{Model specification}

\subsubsection{Dependent variables}

In this study, a person's civic participation is measured by two different variables: participation in political organizations and participation in non-political charitable organizations. The first dependent variable is whether a person joined, worked on, or 
volunteered for a group taking a stand on political issues and the second dependent variable is whether a person joined, worked on, or volunteered for a non-political or charitable group. Regardless of organizational types, a person's participation in civic engagement is largely based on one's attitudes towards social problems and the level of prosocial motivation. Therefore, there may exist a positive correlation between participation in a political group and participation in non-political charitable group. Since estimating a separate equation for each type of engagement ignores the joint distribution of the two dependent variables, this study employs bivariate probit regression in order to account for the correlation between their error terms (Greene, 2012).

\subsubsection{Independent variables}

The independent variables consist of the following three different types of social ties on SNSs: the number of one's Facebook Friends, the number of one's Twitter followers, and the number of other users one follows on Twitter. The survey questions did not ask respondents to provide the exact numbers of network ties, but instead they offered different categories for their network size from which respondents could choose. For Facebook friends, there are 9 categories of 1-99, 100-199, 200-299, 300-399, 400-499, 500-599, 600-699, 700-799, and 800 or more. These categories were numbered from 1 through 9 , in an ascending order, and the numbers 1 through 9 were used in the regression analyses. ${ }^{1}$ If a person did not have a Facebook page, the number of friends was marked as 0 , as he or she had no Facebook-specific social media capital. For the numbers of Twitter followers and people one follows on Twitter, this study uses the four categories of fewer than 25, 25-50, 51-100, and more than 100, replicating how they were specified in the survey. The numbers 1 through 4 are used for this variable, and it takes the value of 0 if a person did not have a Twitter account. The distribution across these categories is available in Table 1.

\subsubsection{Control variables}

This study controls for a set of demographic and other personal characteristics that can affect a person's civic engagement.

SNS usage Research reports mixed findings regarding the relationship between people's social media usage and civic participation, and there exist debates about the direction of the relationship. For instance, Lee (2020) finds a bell-shaped relationship between millennials' Facebook use and frequency of volunteering, while Junco (2012) reports a negative correlation between college students' Facebook usage and

\footnotetext{
1 Treating ordinal variables as if they conform to interval scales assumes equidistance between categories, and doing so can result in biased estimates (Lalla, 2017; Rhemtulla et al., 2012). However, it is not possible to breakdown each category given how the survey was designed. Studies, however, suggest that the bias from equidistance assumption tends to diminish as the number of categories increases, such that the results are unbiased when the number of categories reaches four (Rhemtulla et al., 2012).
} 
Table 1 Sample description $(\mathrm{N}=1,199)$

\begin{tabular}{|c|c|c|c|c|c|}
\hline Variables & Mean & Min & $\operatorname{Max}$ & More details & \\
\hline Participation in Political Organizations & $16.18 \%$ & 0 & 1 & & \\
\hline $\begin{array}{l}\text { Participation in Non-political Charitable } \\
\text { Organizations }\end{array}$ & $39.78 \%$ & 0 & 1 & & \\
\hline Facebook Friends & 3.33 & 0 & 9 & $\begin{array}{l}0-\text { None } \\
1-\text { Fewer than } 99 \\
2-100 \text { to } 199 \\
3-200 \text { to } 299 \\
4-300 \text { to } 399 \\
5-400 \text { to } 499 \\
6-500 \text { to } 599 \\
7-600 \text { to } 699 \\
8-700 \text { to } 799 \\
9-800 \text { or more }\end{array}$ & $\begin{array}{l}11.02 \% \\
17.81 \% \\
18.93 \% \\
15.66 \% \\
9.55 \% \\
6.45 \% \\
4.82 \% \\
3.27 \% \\
4.30 \% \\
8.13 \%\end{array}$ \\
\hline Twitter Followers & 0.92 & 0 & 3 & $\begin{array}{l}0-\text { None } \\
1-25 \text { or fewer } \\
2-26-100 \\
3-101 \text { or more }\end{array}$ & $\begin{array}{l}52.63 \% \\
20.00 \% \\
10.08 \% \\
17.29 \%\end{array}$ \\
\hline Following on Twitter & 0.97 & 0 & 3 & $\begin{array}{l}0-\text { None } \\
1-25 \text { or fewer } \\
2-26-100 \\
3-101 \text { or more }\end{array}$ & $\begin{array}{l}51.79 \% \\
15.76 \% \\
15.51 \% \\
16.93 \%\end{array}$ \\
\hline Frequency of Facebook Use & 3.36 & 1 & 4 & $\begin{array}{l}1 \text { - Never } \\
2 \text { - less than once a week } \\
3 \text {-1-3 times a week } \\
4 \text { - Daily or more often }\end{array}$ & $\begin{array}{l}10.68 \% \\
9.59 \% \\
12.26 \% \\
67.47 \%\end{array}$ \\
\hline Frequency of Twitter Use & 2.06 & 1 & 4 & $\begin{array}{l}1 \text { - Never } \\
2-\text { less than once a week } \\
3-1-3 \text { times a week } \\
4 \text { - Daily or more often }\end{array}$ & $\begin{array}{l}51.79 \% \\
13.84 \% \\
11.26 \% \\
23.10 \%\end{array}$ \\
\hline No or little Interest in Politics & $42.95 \%$ & 0 & 1 & & \\
\hline Some Interests in Politics & $42.20 \%$ & 0 & 1 & & \\
\hline A Great Deal of Interests in Politics & $14.85 \%$ & 0 & 1 & & \\
\hline No or Little Interest in Local Community & $30.36 \%$ & 0 & 1 & & \\
\hline Some Interests in Local Community & $47.04 \%$ & 0 & 1 & & \\
\hline $\begin{array}{l}\text { A Great Deal of Interests in Local Com- } \\
\text { munity }\end{array}$ & $22.60 \%$ & 0 & 1 & & \\
\hline Women & $53.38 \%$ & 0 & 1 & & \\
\hline Age & $23.05 \mathrm{yrs}$ & 16 & 29 & & \\
\hline White & $71.48 \%$ & 0 & 1 & & \\
\hline Northeast & $18.35 \%$ & 0 & 1 & & \\
\hline Midwest & $38.45 \%$ & 0 & 1 & & \\
\hline South & $21.02 \%$ & 0 & 1 & & \\
\hline West & $21.18 \%$ & 0 & 1 & & \\
\hline
\end{tabular}


their civic engagement. On the other hand, Peak and her colleagues (2013) report that, when individuals' social and demographic characteristics are controlled, there is no statistically significant association between social media use and civic engagement behaviors. In their study, how much a person uses SNSs is controlled to account for the potential impact of social media usage on civic engagement. The regression model for Facebook friends and civic engagement includes a variable of how often a person used Facebook in four different levels of never, less than three times a month, 1-3 times a week, and daily or more often. Similarly, Twitter usage is controlled in the Twitter followers and following models, using the same set of four different levels.

Attention to politics and community affairs Individual participation in civic engagement, to a great extent, is determined by their interests in social issues and problems. Hence, variations in one's interests in political and community affairs need to be taken into consideration when studying the social media capital-civic engagement relationship. The model includes two variables of one's attention to politics and attention to local community, based on the two questions of "How much attention do you pay to news about politics?" and "How much attention do you pay to news about your local community?." Respondents answered to these questions in a 4-point Likert type scale of "not at all," "not much attention," "some attention," and "a great deal of attention." Two dummy variables of "some attention" and "a great deal of attention" are included in the model, with "no or not much attention" as the base category. Table 1 shows the sample distribution across the three categories.

Gender Research finds that there are gender differences in individual civic engagement patterns (Lee \& Brudney, 2012; Taniguchi, 2006). Studies on social media use also report that the psychological and behavioral implications of SNS usage differ by gender (Nesi \& Prinstein, 2015). The regression models control for one's gender ( 1 if female and 0 otherwise).

Age Rates of various civic engagement activities vary across one's life course (Wilson, 2000). Although the survey was conducted on young people (ages between 16 and 29), there may still be differences according to one's age. This study controls for a person's age at the time of the survey.

Race Research on volunteering reports a significant racial gap in formal volunteering, defined as contribution of unpaid time to the activities of organizations or established entities, with whites participating at a higher rate than non-white (Lee \& Brudney, 2012). As this study examines young people's participation in civic engagement through a formal organization, the model controls for racial minority/ non-minority status - whether they identified themselves as white/Caucasian (1 if they did and 0 otherwise).

Census region This study controls for four different regions in the United StatesNortheast, Midwest, South and West (the base category). 
Table 2 Bivariate Probit Results: Facebook Friends

Participation in Politi- Participation in Non-politcal Organizations ical Charitable Organizations

\begin{tabular}{|c|c|c|}
\hline Variables & $\begin{array}{l}\text { Coefficient } \\
\text { (Standard error) }\end{array}$ & $\begin{array}{l}\text { Coefficient } \\
\text { (Standard error) }\end{array}$ \\
\hline Facebook Friends & $\begin{array}{l}0.0642 * * \\
(0.0188)\end{array}$ & $\begin{array}{l}0.0679 * * * \\
(0.0160)\end{array}$ \\
\hline Frequency of Facebook Use & $\begin{array}{l}-0.1035^{*} \\
(0.0505)\end{array}$ & $\begin{array}{l}-0.0511 \\
(0.0420)\end{array}$ \\
\hline Some Interests in Politics & $\begin{array}{l}0.6478 * * * \\
(0.1155)\end{array}$ & $\begin{array}{l}0.4206 * * * \\
(0.0866)\end{array}$ \\
\hline A Great Deal of Interests in Politics & $\begin{array}{l}1.1474 * * * \\
(0.1464)\end{array}$ & $\begin{array}{l}0.4700 * * * \\
(0.1276)\end{array}$ \\
\hline Some Interests in Local Community & $\begin{array}{l}-0.1040 \\
(0.1171)\end{array}$ & $\begin{array}{l}-0.1209 \\
(0.0919)\end{array}$ \\
\hline A Great Deal of Interests in Local Community & $\begin{array}{l}0.2237 \\
(0.1349)\end{array}$ & $\begin{array}{l}0.2293^{*} \\
(0.1146)\end{array}$ \\
\hline Women & $\begin{array}{l}-0.2512^{*} \\
(0.0978)\end{array}$ & $\begin{array}{l}0.2286 * * \\
(0.0807)\end{array}$ \\
\hline Age & $\begin{array}{l}-0.0266 \\
(0.0132)\end{array}$ & $\begin{array}{l}-0.0331 \\
(0.0108)\end{array}$ \\
\hline White & $\begin{array}{l}-0.0354 \\
(0.1035)\end{array}$ & $\begin{array}{l}0.0764 \\
(0.0860)\end{array}$ \\
\hline Northeast & $\begin{array}{l}0.2085 \\
(0.1469)\end{array}$ & $\begin{array}{l}0.0064 \\
(0.1185)\end{array}$ \\
\hline Midwest & $\begin{array}{l}0.0807 \\
(0.1308)\end{array}$ & $\begin{array}{l}-0.1418 \\
(0.1027)\end{array}$ \\
\hline South & $\begin{array}{l}0.2121 \\
(0.1459)\end{array}$ & $\begin{array}{l}0.0314 \\
(0.1180)\end{array}$ \\
\hline /athrho & $\begin{array}{l}0.6488 \\
(0.0682)\end{array}$ & \\
\hline rho & $\begin{array}{l}0.5709 \\
(0.0460)\end{array}$ & \\
\hline
\end{tabular}

LR test of rho $=0: \mathrm{Chi}^{2}(1)=103.856$, Prob $>$ Chi $2=0.0000$.

Wald Chi2(24) $=187.07$.

Log likelihood $=-1155.9736$.

Statistical significance levels are $* * * \mathrm{p}<0.001, * * \mathrm{p}<0.01$, and $* \mathrm{p}<0.05$.

\section{Regression Results}

Tables 2, 3 and 4 show the bivariate probit results of the three models with Facebook friends, Twitter followers, and Twitter following as independent variables, respectively. The regression results exhibit positive relationships between all three types of connections and a person's participation in both political and nonpolitical charitable organizations. Increases in the number of Facebook friends, 
Table 3 Bivariate Probit Results: Twitter Followers

\begin{tabular}{|c|c|c|}
\hline & $\begin{array}{l}\text { Participation in Politi- } \\
\text { cal Organizations }\end{array}$ & $\begin{array}{l}\text { Participation in Non-polit- } \\
\text { ical Charitable Organiza- } \\
\text { tions }\end{array}$ \\
\hline Variables & $\begin{array}{l}\text { Coefficient } \\
\text { (Standard error) }\end{array}$ & $\begin{array}{l}\text { Coefficient } \\
\text { (Standard error) }\end{array}$ \\
\hline Twitter Followers & $\begin{array}{l}0.4128 * * * \\
(0.0776)\end{array}$ & $\begin{array}{l}0.2038 * * \\
(0.0664)\end{array}$ \\
\hline Frequency of Twitter Use & $\begin{array}{l}-0.1515^{*} \\
(0.0738)\end{array}$ & $\begin{array}{l}-0.0872 \\
(0.0615)\end{array}$ \\
\hline Some Interests in Politics & $\begin{array}{l}0.6723 * * * \\
(0.1178)\end{array}$ & $\begin{array}{l}0.4404 * * * \\
(0.0869)\end{array}$ \\
\hline A Great Deal of Interests in Politics & $\begin{array}{l}1.1560 * * * \\
(0.1483)\end{array}$ & $\begin{array}{l}0.5080 * * * \\
(0.1269)\end{array}$ \\
\hline Some Interests in Local Community & $\begin{array}{l}-0.1886 \\
(0.1196)\end{array}$ & $\begin{array}{l}-0.1122 \\
(0.0923)\end{array}$ \\
\hline A Great Deal of Interests in Local Community & $\begin{array}{l}0.1538 \\
(0.1360)\end{array}$ & $\begin{array}{l}0.2147 \\
(0.1139)\end{array}$ \\
\hline Women & $\begin{array}{l}-0.2695 * * \\
(0.0996)\end{array}$ & $\begin{array}{l}0.2312 * * \\
(0.0800)\end{array}$ \\
\hline Age & $\begin{array}{l}-0.0231 \\
(0.0135)\end{array}$ & $\begin{array}{l}-0.036 * * \\
(0.0107)\end{array}$ \\
\hline White & $\begin{array}{l}0.0238 \\
(0.1064)\end{array}$ & $\begin{array}{l}0.0672 \\
(0.0861)\end{array}$ \\
\hline Northeast & $\begin{array}{l}0.2004 \\
(0.1509)\end{array}$ & $\begin{array}{l}0.0375 \\
(0.1195)\end{array}$ \\
\hline Midwest & $\begin{array}{l}0.0904 \\
(0.1328)\end{array}$ & $\begin{array}{l}-0.1165 \\
(0.1020)\end{array}$ \\
\hline South & $\begin{array}{l}0.1819 \\
(0.1488)\end{array}$ & $\begin{array}{l}0.0822 \\
(0.1172)\end{array}$ \\
\hline /athrho & $\begin{array}{l}0.6166 \\
(0.0686)\end{array}$ & \\
\hline rho & $\begin{array}{l}0.5487 \\
(0.0479)\end{array}$ & \\
\hline
\end{tabular}

LR test of rho $=0: \mathrm{Chi}^{2}(1)=94.0533$, Prob $>$ Chi $2=0.0000$.

Wald Chi2 $(24)=214.03$.

Log likelihood $=-1138.0272$.

Statistical significance levels are $* * * \mathrm{p}<0.001,{ }^{*} \mathrm{p}<0.01$, and $* \mathrm{p}<0.05$.

Twitter followers and the people one follows on Twitter, predict an increased likelihood of one's participation in civic engagement via both types of organizations.

Results in Tables 2, 3 and 4 also indicate that a person's attention to politics is positively correlated with the likelihood of participation in both political and nonpolitical charitable associations. That is, as one's attention to politics increases, so does the likelihood of civic engagement activities in both types of organizations. However, one's attention to local community affairs is not statistically significantly associated with civic participation in general. The results of the Facebook 
Table 4 Bivariate Probit Results: Twitter Following

Participation in Politi- Participation in Non-politcal Organizations ical Charitable Organizations

\begin{tabular}{|c|c|c|}
\hline Variables & $\begin{array}{l}\text { Coefficient } \\
\text { (Standard error) }\end{array}$ & $\begin{array}{l}\text { Coefficient } \\
\text { (Standard error) }\end{array}$ \\
\hline Following on Twitter & $\begin{array}{l}0.4808 * * * \\
(0.0819)\end{array}$ & $\begin{array}{l}0.2418^{* * * *} \\
(0.0689)\end{array}$ \\
\hline Frequency of Twitter Use & $\begin{array}{l}-0.2199 * * \\
(0.0788)\end{array}$ & $\begin{array}{l}-0.1269 \\
(0.0649)\end{array}$ \\
\hline Some Interests in Politics & $\begin{array}{l}0.6919 * * * \\
(0.1180)\end{array}$ & $\begin{array}{l}0.4494 * * * \\
(0.0864)\end{array}$ \\
\hline A Great Deal of Interests in Politics & $\begin{array}{l}1.1742 * * * \\
(0.1484)\end{array}$ & $\begin{array}{l}0.5085^{* * *} \\
(0.1263)\end{array}$ \\
\hline Some Interests in Local Community & $\begin{array}{l}-0.2165 \\
(0.1195)\end{array}$ & $\begin{array}{l}-0.1194 \\
(0.0918)\end{array}$ \\
\hline A Great Deal of Interests in Local Community & $\begin{array}{l}0.1730 \\
(0.1353)\end{array}$ & $\begin{array}{l}0.2197 \\
(0.1134)\end{array}$ \\
\hline Women & $\begin{array}{l}-0.2467 * \\
(0.0992)\end{array}$ & $\begin{array}{l}0.2541 * * \\
(0.0795)\end{array}$ \\
\hline Age & $\begin{array}{l}-0.0255 \\
(0.0134)\end{array}$ & $\begin{array}{l}-0.0354 * * \\
(0.0106)\end{array}$ \\
\hline White & $\begin{array}{l}0.0029 \\
(0.1059)\end{array}$ & $\begin{array}{l}0.0536 \\
(0.0854)\end{array}$ \\
\hline Northeast & $\begin{array}{l}0.2046 \\
(0.1519)\end{array}$ & $\begin{array}{l}0.0365 \\
(0.1189)\end{array}$ \\
\hline Midwest & $\begin{array}{l}0.1013 \\
(0.1330)\end{array}$ & $\begin{array}{l}-0.1328 \\
(0.1014)\end{array}$ \\
\hline South & $\begin{array}{l}0.2333 \\
(0.1478)\end{array}$ & $\begin{array}{l}0.0810 \\
(0.1171)\end{array}$ \\
\hline /athrho & $\begin{array}{l}0.6156 \\
(0.2835)\end{array}$ & \\
\hline rho & $\begin{array}{l}0.5481 \\
(0.0479)\end{array}$ & \\
\hline
\end{tabular}

LR test of rho $=0: \mathrm{Chi}^{2}(1)=91.6368$, Prob $>\mathrm{Chi} 2=0.0000$.

Wald Chi2 $(26)=222.93$.

Log likelihood $=-1146.761$.

Statistical significance levels are $* * * \mathrm{p}<0.001, * * \mathrm{p}<0.01$, and $* \mathrm{p}<0.05$.

friends-civic engagement regression in Table 2 show that individuals who pay a great deal of attention to local community affairs are more likely to participate in non-political charitable organizations than are people with no or little attention, but the results are not replicated in the case of Twitter connections (Tables 3 and 4). The findings suggest that the accumulation of social networks on SNS has different civic engagement implications between the two platforms.

In terms of the SNS usage-civic engagement relationship, the results in Tables 2, 3 and 4 reveal that the likelihood of participation in political 
organizations decreases with the frequency of usage, while the likelihood of participation in non-political and charitable organizations does not change based on SNS usage frequency. This relationship holds for both Facebook and Twitter connections. The results also show an interesting, gendered pattern in civic participation. Specifically, men are more likely to participate in political organizations than women, controlling for other characteristics. On the other hand, women are more likely to participate in non-political charitable organizations than men. The results also indicate that participation in political association is not predicted by age, but there exists a negative correlation between age and participation in nonpolitical and charitable groups. There is no statistically significant difference in civic participation between whites and non-whites or across regions (Tables 2, 3, and 4).

While the results show a positive link between social media capital and civic engagement in general, the comparison across the three different social ties and between the two organizational contexts reveal unique patterns in the social media capital-civic engagement link. The results of the two Twitter regressions in Tables 3 and 4 show that the regression coefficients for participation in a political organization are about twice as large as the coefficients for participation in a nonpolitical charitable organization ( 0.41 and 0.20 for Twitter followers and 0.48 and 0.24 for Twitter following). In contrast, the results of the Facebook regression in Table 2 show that the coefficient for participation in non-political charitable organizations is larger than the coefficient for participation in political organizations although the difference is small (0.06 and 0.07).

Because the regression coefficients in the bivariate probit model do not tell the magnitude of the effects, and the marginal effects after the bivariate probit are provided in Tables 5, 6 and 7. Most noticeably, the marginal effects reveal distinctive patterns of social media capital-civic engagement on Twitter. Tables 6 and 7 show that, when all other variables are held at their mean values, a one-level increase in one's followers and the people one follows increases the likelihood of participation in a political organization only (by 2 percent), but it decreases the likelihood of participation in a charitable organization only. The marginal effects of the Facebook regression in Table 5 reveal an opposite pattern: a one-level increase in a person's Facebook Friends increases the likelihood of participating a non-political and charitable organization only (by 1 percent), but it does affect the likelihood of participating in political organizations only.

The marginal effects in Tables 5, 6, and 7 indicate that an individual's attention to politics increases the likelihood of participating in both types of organization as well as participating in political organizations. Interests to community affairs, however, do not affect the likelihood of participation. The results also show that women are approximately 3 percent less likely to participate only in political organizations, but they are 11-12 percent more likely to participate only in nonpolitical charitable organizations. Tables 5, 6 and 7 reveal that, as age increases by one year, a person's likelihood of non-participation increases by 1.3-1.4 percent. The likelihood of participating in both types of organizations decreases with age by a 0.5 percentage point. 


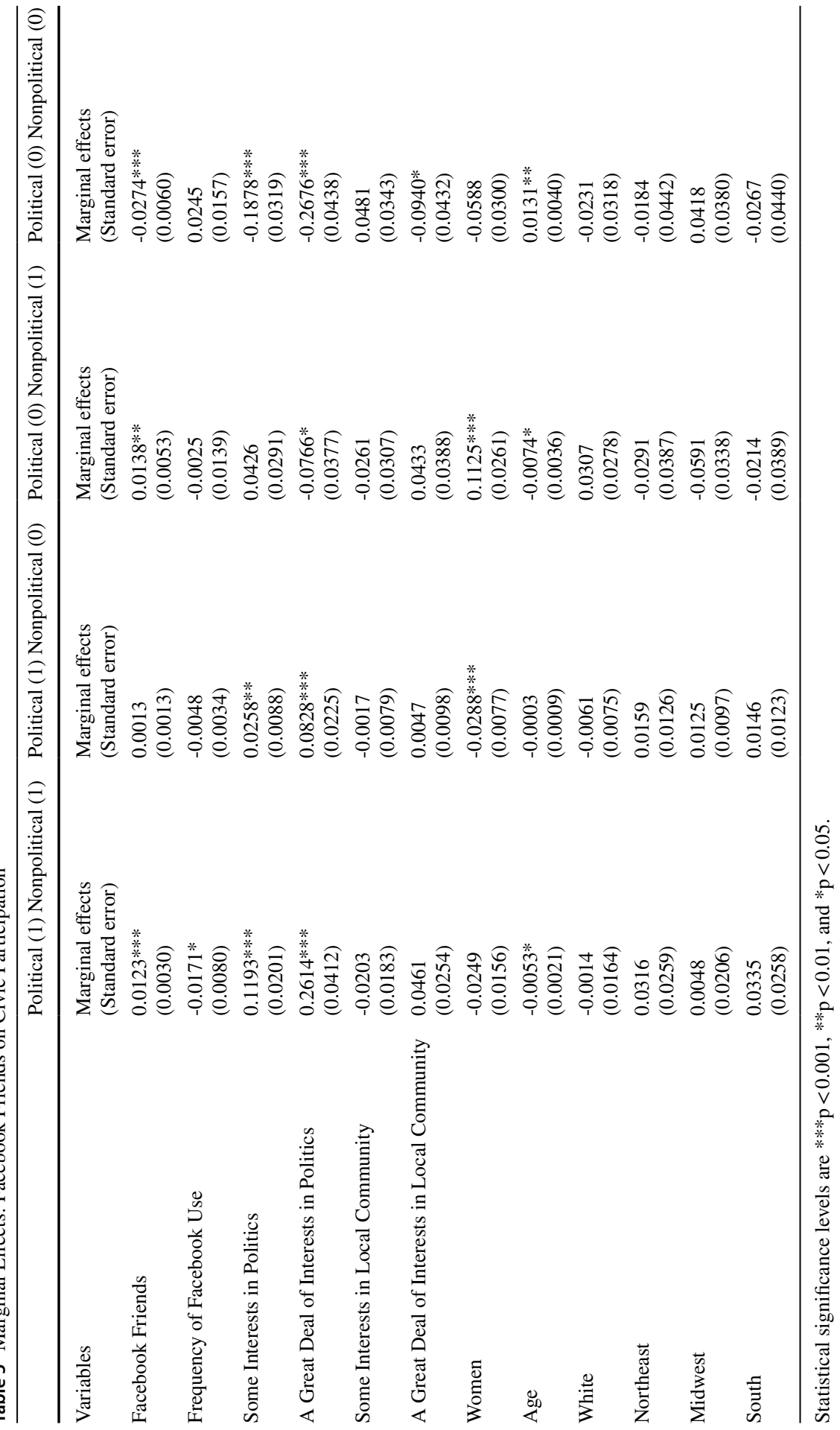




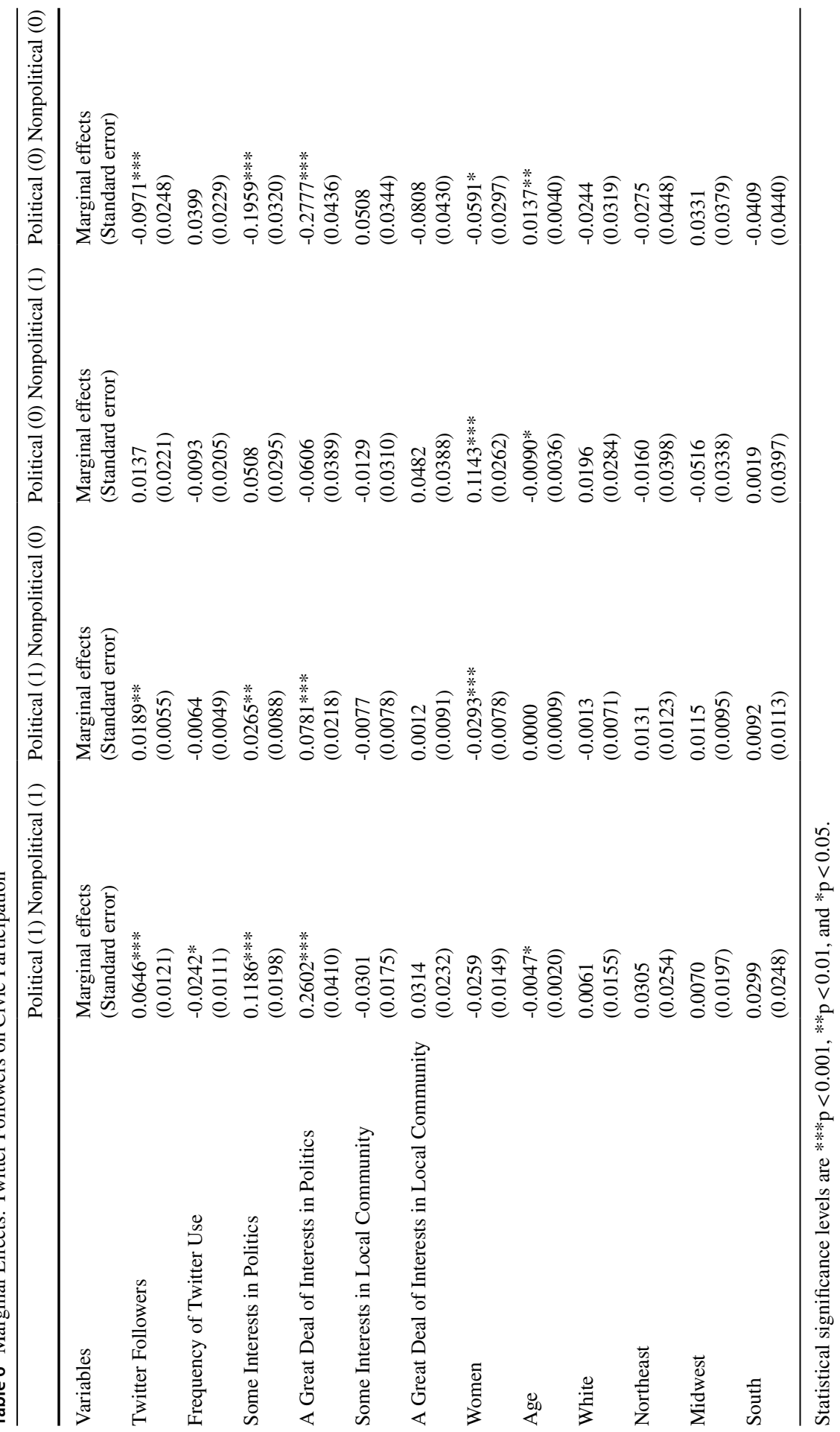




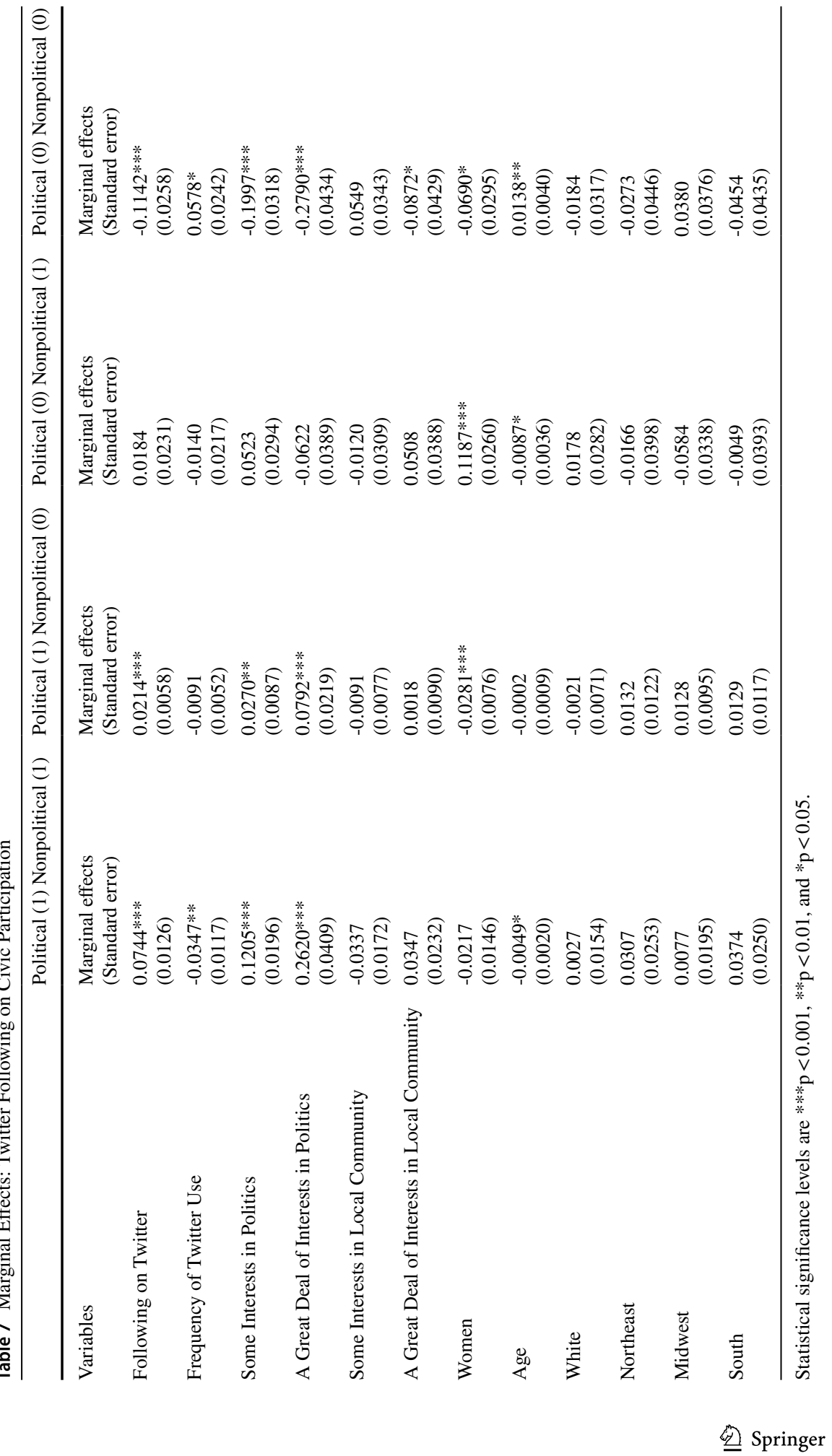




\section{Discussion}

This study examined how a person's social media capital, measured by one's network size on SNSs, relates to one's civic engagement. By examining three different types of social connections developed in two SNSs with distinctive characteristics, the findings of this study contribute to better understanding social media capital's behavioral implications. Specifically, this study tested how the number of social ties young people have on Facebook and Twitter, the two most popular platforms, predicts their civic participation via political organizations and nonpolitical charitable organizations.

The findings show that one's social media capital, measured in three different ways (Facebook friends, Twitter followers and Twitter following), is positively associated with civic participation in both types of organizations, suggesting that young people's social media capital, regardless of platform and forms, has potential for promoting civic engagement. At the same time, the analysis reveals that there exist differences between Facebook and Twitter social capital. The comparison of marginal effects for participation in political groups and participation in non-political charitable groups in Twitter models suggests that the number of social ties on Twitter, in both terms of "follower" and "following," is a better predictor of civic participation via political organizations than participation via non-political charitable organizations. Facebook social capital, on the other hand, is a better predictor of participation via non-political charitable organizations. The findings also reveal that an increased attention to local community predicts an increase in the likelihood of civic engagement via non-political and charitable organizations in the Facebook regression. However, the relationship does not exist in the two Twitter regressions. The differences in the civic engagement implications between Facebook social capital and Twitter social capital found in this study suggest that the one's social capital built in different social media platforms have distinctive civic engagement implications (Phua et al., 2017). In addition, comparing the results of Twitter following and follower regressions suggest that the number of people a person follows predicts one's civic engagement better than does the number of a person's followers. These findings are consistent with the existing research reporting a significant difference in social capital implications of following someone vs. being followed on Twitter (Hofer \& Aubert, 2013; Smith \& Giraud-Carrier, 2010). In summary, the findings provide an evidence that the nature of social media capital is unique to a particular platform and types of connections.

Despite the found patterns of social media capital-civic engagement relationships, the data limitation prevents exact predictions of the network size and the likelihood of civic participation relationship. Because the survey used ranges of a person's network size, instead of the actual number of ties, this study cannot examine how having 100 more Facebook Friends and having 100 more Twitter followers are differently associated with the likelihood of civic engagement. It is also impossible to estimate how the likelihood changes when a person has 99 Twitter followers versus 66 followers and when a person's network size exceeds 
the top threshold substantially, for instance, the difference in civic engagement implications between having 800 Facebook friends and having 2000 friends. Moreover, the survey relies on self-reported information on the size of one's social media network and SNS use, and research suggests a gap between the selfreported information and actual social media capital (Junco, 2013). Future studies should collect exact numbers of social connections and other usage stats so that they will contribute to improved knowledge on the association between social media capital and civic engagement.

There are some other limitations that need to be acknowledged. First, this study uses the 2013 survey data, and platforms have continued to evolve since. The constantly changing social media environment may prevent the generalization of the findings, and research using more recent data will help better understand the relationship between social media capital and civic engagement. Second, the survey was targeted to young people (ages 16-29), and involving a wider range of age group will help understand the generational differences in social media use and prosocial behaviors. Nevertheless, considering that this age group coincide with the Y generation, the findings of this study can offer insights unto millennials' SNS activities and civic engagement. Another data limitation derives from the unequal representation of regions in the survey: approximately 40 percent of the sample resided in Midwest (Table 1). In the U.S., more people live in South than in other regions (US Census Bureau, 2019), the proportions of respondents across the four regions in the sample do not reflect overall population distribution in the nation.

Today's nonprofits utilize various online platforms that connect volunteers and volunteering opportunities, and the rapid development of such tools in the past decade could have affected the relationship between social media capital and civic engagement behaviors. In particular, during the COVID-19 pandemic, volunteers relied more heavily on online platforms to identify people in need than ever, and more donations were made online than in offline events (Trautwein et al., 2020). Further, although this study uses a dichotomous variable of participation, civic engagement compasses a wide range of activities, including volunteering, participating in marches, and voting. Studying how people's online activities relate to various civic engagement activities will, therefore, contribute to better understanding the role of online social capital built on different platforms in a person's civic engagement. Currently, there are many different types of platforms available, and each platform may have distinct civic engagement implication. While this study focused on Facebook and Twitter, the most widely used platforms, future study should examine how social media capital accumulated via various platforms has distinct civic engagement implications.

Lastly, there exists a variety of definitions of social capital across different fields of study (Adler \& Kwon, 2002), and social capital is an elusive concept, making its measurement a challenge (Williams, 2006). Accordingly, there is no perfect measure of social capital, and research relies on a variety of indices, including the number of associational memberships and the number of friends, to quantify a person's social connectedness (Putnam, 2001). Compared with the existing measures that are highly subjective and difficult to measure (one's definition of "friends" can differ from one person to another), the measures of social 
capital used in this study are straightforward and readily qualifiable. The significant association between social media connections and civic engagement suggest that one's stock of social media capital be utilized for developing a scale of social capital. Nevertheless, developing a better measurement of online social capital, by studying what people actually do on social media and creating different levels of profiles for instance, will definitely illuminate the online social capital and civic engagement relationship. This information is not available in the data, but future research should examine the actual participation in social media and design a more detailed measure of online social capital. Future research can also look into the intertwinement between traditional offline social capital and social media capital in the current digital environment and the multiple possibilities regarding the directionality of the relationship.

\section{Conclusions}

The literature suggests that civic life enhances democratic institutions, emphasizing the social capital's contribution to democracy (Putnam, 2000). Many scholars also have stressed the important role of social media capital in promoting young people's participation in civil society via digital democracy (Alex-Assensoh, 2002; Schlosberg \& Dryzek, 2002). Despite the criticisms about young people's use of social media and the increasing concerns that the changing ways of social interactions contribute to the younger generation's narcissism and social isolation, the findings reveal the potential of virtual social ties in boosting young people's civic engagement and prosocial behaviors. SNSs provide new possibilities for bottom-up and self-organizing participation for bypassing traditional mass media whose gatekeepers can control the one-way communication (Kaun \& Uldam, 2018). Such possibilities may trigger social media capital's positive impacts on individual and collective civic engagement. The positive association between the three forms of virtual social capital and young Americans' civic engagement in both political and non-political organizations found in this study expands SNSs' role beyond digital democracy, to a variety of civic engagement behaviors that contribute to strengthening democratic institutions. Hence, the findings of this study suggest that a nonprofit organization's investment in social media management has potential to increase its stakeholders' engagement and contribution.

Further, the findings imply that distinctive motivations are associated with one's use of different platforms, and one platform can be more effective than others in boosting civic participation depending on the type of engagement. These findings suggest that research on social media capital's behavioral implications take the platform-specific context into consideration. Today's nonprofit organizations interact with their stakeholders, including donors and volunteers, on social media, and how to elicit desired behaviors from the stakeholders has a tremendous strategic importance (Hong \& Li, 2020). The findings of this study suggest that nonprofit organizations take the platform specific culture into consideration when planning 
their communication and marketing strategies, and their social media strategies be tailored to the unique resource needs and target audience of the organization.

\section{References}

Adler, P. S., \& Kwon, S. W. (2002). Social capital: Prospects for a new concept. Academy of Management Review, 27(1), 17-40.

Alex-Assensoh, Y. M. (2002). Social capital, civic engagement, and the importance of context. McLean, S. L., Schultz, D. A., \& Steger, M.B. (eds). Social capital: Critical perspectives on Community and "Bowling Alone", 203-217.

Bargh, J. A., \& McKenna, K. Y. (2004). The Internet and social life. Annual Review of Psychology, $55,573-590$

Best, S. J., \& Krueger, B. S. (2006). Online interactions and social capital: Distinguishing between new and existing ties. Social Science Computer Review, 24(4), 395-410.

Bourdieu, P. (1986). The forms of social capital. In J. G. Richardson (Ed.), Handbook of theory and research for the sociology of education (pp. 241-258). Greenwood.

Boyd, D. M., \& Ellison, N. B. (2007). Social network sites: Definition, history, and scholarship. Journal of Computer-Mediated Communication, 13(1), 210-230.

Brown, E., \& Ferris, J. M. (2007). Social capital and philanthropy: An analysis of the impact of social capital on individual giving and volunteering. Nonprofit and Voluntary Sector Quarterly, 36(1), 85-99.

Chiu, C. M., Hsu, M. H., \& Wang, E. T. (2006). Understanding knowledge sharing in virtual communities: An integration of social capital and social cognitive theories. Decision Support Systems, 42(3), 1872-1888.

Clark, J. L., Algoe, S. B., \& Green, M. C. (2018). Social network sites and well-being: The role of social connection. Current Directions in Psychological Science, 27(1), 32-37.

Clark, M., \& Melancon, J. (2013). The influence of social media investment on relational outcomes: A relationship marketing perspective. International Journal of Marketing Studies, 5(4), 132.

Coleman, J. S. (1988). Social capital in the creation of human capital. American Journal of Sociology, 94, S95-S120.

Conroy, M., Feezell, J. T., \& Guerrero, M. (2012). Facebook and political engagement: A study of online political group membership and offline political engagement. Computers in Human Behavior, 28(5), 1535-1546.

Davenport, S. W., Bergman, S. M., Bergman, J. Z., \& Fearrington, M. E. (2014). Twitter versus Facebook: Exploring the role of narcissism in the motives and usage of different social media platforms. Computers in Human Behavior, 32, 212-220.

De Zúñiga, H. G., Barnidge, M., \& Scherman, A. (2017). Social media social capital, offline social capital, and citizenship: Exploring asymmetrical social capital effects. Political Communication, 34(1), 44-68.

De Zúñiga, H. G., \& Valenzuela, S. (2011). The mediating path to a stronger citizenship: Online and offline networks, weak ties, and civic engagement. Communication Research, 38(3), 397-421.

Ellison, N. B., Lampe, C., \& Steinfield, C. (2010). With a little help from my friends: How social network sites affect social capital processes. A networked self: Identity, community and culture on social network sites (pp. 132-153). Routledge.

Ellison, N. B., Steinfield, C., \& Lampe, C. (2007). The benefits of Facebook "friends:" Social capital and college students' use of online social network sites. Journal of Computer-Mediated Communication, 12(4), 1143-1168.

Ellison, N. B., Vitak, J., Steinfield, C., Gray, R., \& Lampe, C. (2011). Negotiating privacy concerns and social capital needs in a social media environment. In Privacy online (pp. 19-32). Springer, Berlin, Heidelberg.

Errasti, J., Amigo, I., \& Villadangos, M. (2017). Emotional uses of Facebook and Twitter: Its relation with empathy, narcissism, and self-esteem in adolescence. Psychological Reports, 120(6), 997-1018. 
Gavrilutăă, C., \& Bortoş, S. (2020). UAICCrush-Love 2.0. A Study on Virtual Forms of Student Relationships. Bulletin of the Transilvania University of Brasov. Series VII, Social Sciences and Law, 13(1), 63-70.

Glanville, J. L., Paxton, P., \& Wang, Y. (2016). Social capital and generosity: A multilevel analysis. Nonprofit and Voluntary Sector Quarterly, 45(3), 526-547.

Greene, W. H. (2012). Econometric analysis. Prentice Hall.

Hampton, K. N., Goulet, L. S., Marlow, C., \& Rainie, L. (2012). Why most Facebook users get more than they give. Pew Internet \& American Life Project, 3(2012), 1-40.

Harasim, L. M. (1993). Networlds: Networks as social space. Global networks: Computers and International Communication, 15-34.

Harlow, S. (2012). Social media and social movements: Facebook and an online Guatemalan justice movement that moved offline. New Media \& Society, 14(2), 225-243.

Hofer, M., \& Aubert, V. (2013). Perceived bridging and bonding social capital on Twitter: Differentiating between followers and followees. Computers in Human Behavior, 29(6), 2134-2142.

Hong, C., \& Li, C. (2020). How to turn lurkers into donors? A study of online social support interactions between nonprofit organizations and their followers. International Review on Public and Nonprofit Marketing, 17(4), 527-547.

Hughes, D. J., Rowe, M., Batey, M., \& Lee, A. (2012). A tale of two sites: Twitter vs. Facebook and the personality predictors of social media usage. Computers in Human Behavior, 28(2), 561-569.

Johnston, K., Tanner, M., Lalla, N., \& Kawalski, D. (2013). Social capital: The benefit of Facebook 'friends.' Behaviour \& Information Technology, 32(1), 24-36.

Junco, R. (2012). The relationship between frequency of Facebook use, participation in Facebook activities, and student engagement. Computers \& Education, 58(1), 162-171.

Junco, R. (2013). Comparing actual and self-reported measures of Facebook use. Computers in Human Behavior, 29(3), 626-631.

Kaun, A., \& Uldam, J. (2018). 'Volunteering is like any other business': Civic participation and social media. New Media \& Society, 20(6), 2186-2207.

Kristofferson, K., White, K., \& Peloza, J. (2014). The nature of slacktivism: How the social observability of an initial act of token support affects subsequent prosocial action. Journal of Consumer Research, 40(6), 1149-1166.

Lalla, M. (2017). Fundamental characteristics and statistical analysis of ordinal variables: A review. Quality \& Quantity, 51(1), 435-458.

Lane, D. S., \& Dal Cin, S. (2018). Sharing beyond Slacktivism: The effect of socially observable prosocial media sharing on subsequent offline helping behavior. Information, Communication \& Society, 21(11), 1523-1540.

Lee, Y. J. (2020). Facebooking alone?: Millennials' use of social network sites and volunteering. Nonprofit and Voluntary Sector Quarterly, 49(1), 203-217.

Lee, Y. J., \& Brudney, J. L. (2012). Participation in formal and informal volunteering: Implications for volunteer recruitment. Nonprofit Management and Leadership, 23(2), 159-180.

Lin, L. Y., Sidani, J. E., Shensa, A., Radovic, A., Miller, E., Colditz, J. B., ... \& Primack, B. A. (2016). Association between social media use and depression among US young adults. Depression and Anxiety, 33(4), 323-331.

Mandarano, L., Meenar, M., \& Steins, C. (2010). Building social capital in the digital age of civic engagement. Journal of Planning Literature, 25(2), 123-135.

Matos, M., \& Fernandes, T. (2021). Volunteer engagement: drivers and outcomes on non-profits' cocreation of value. International Review on Public and Nonprofit Marketing, 1-20.

Mayer, A., \& Puller, S. L. (2008). The old boy (and girl) network: Social network formation on university campuses. Journal of Public Economics, 92(1-2), 329-347.

McCain, J. L., \& Campbell, W. K. (2018). Narcissism and social media use: A meta-analytic review. Psychology of Popular Media Culture, 7(3), 308-327.

Mosconi, G., Korn, M., Reuter, C., Tolmie, P., Teli, M., \& Pipek, V. (2017). From facebook to the neighbourhood: Infrastructuring of hybrid community engagement. Computer Supported Cooperative Work (CSCW), 26(4-6), 959-1003.

Nesi, J., \& Prinstein, M. J. (2015). Using social media for social comparison and feedback-seeking: Gender and popularity moderate associations with depressive symptoms. Journal of Abnormal Child Psychology, 43(8), 1427-1438.

Paek, H. J., Hove, T., Jung, Y., \& Cole, R. T. (2013). Engagement across three social media platforms: An exploratory study of a cause-related PR campaign. Public Relations Review, 39(5), 526-533. 
Pasek, J., More, E., \& Romer, D. (2009). Realizing the social Internet? Online social networking meets offline civic engagement. Journal of Information Technology \& Politics, 6(3-4), 197-215.

Pénard, T., \& Poussing, N. (2010). Internet use and social capital: The strength of virtual ties. Journal of Economic Issues, 44(3), 569-595.

Phua, J., Jin, S. V., \& Kim, J. J. (2017). Uses and gratifications of social networking sites for bridging and bonding social capital: A comparison of Facebook, Twitter, Instagram, and Snapchat. Computers in Human Behavior, 72, 115-122.

Portes, A. (1998). Social capital: Its origins and applications in modern sociology. Annual Review of Sociology, 24(1), 1-24.

Putnam, R. (2001). Social capital: Measurement and consequences. Canadian Journal of Policy Research, 2(1), 41-51.

Putnam, R. D. (2000). Bowling alone: The collapse and revival of American community. Simon and Schuster.

Ramirez, A., Jr., Sumner, E. M., \& Spinda, J. (2017). The relational reconnection function of social network sites. New Media \& Society, 19(6), 807-825.

Rhemtulla, M., Brosseau-Liard, P. É., \& Savalei, V. (2012). When can categorical variables be treated as continuous? A comparison of robust continuous and categorical SEM estimation methods under suboptimal conditions. Psychological Methods, 17(3), 354.

Saxton, G. D., \& Guo, C. (2020). Social media capital: Conceptualizing the nature, acquisition, and expenditure of social media-based organizational resources. International Journal of Accounting Information Systems, 100443.

Schlosberg, D., \& Dryzek, J. S. (2002). Digital democracy: Authentic or virtual? Organization \& Environment, 15(3), 332-335.

Schofer, E., \& Fourcade-Gourinchas, M. (2001). The structural contexts of civic engagement: Voluntary association membership in comparative perspective. American Sociological Review, 806-828.

Shane-Simpson, C., Manago, A., Gaggi, N., \& Gillespie-Lynch, K. (2018). Why do college students prefer Facebook, Twitter, or Instagram? Site affordances, tensions between privacy and self-expression, and implications for social capital. Computers in Human Behavior, 86, 276-288.

Smith, M. S. \& Giraud-Carrier, C. (2010). Bonding vs. bridging social capital: A case study in Twitter. In 2010 IEEE Second International Conference on Social Computing (pp. 385-392). IEEE.

Taniguchi, H. (2006). Men's and women's volunteering: Gender differences in the effects of employment and family characteristics. Nonprofit and Voluntary Sector Quarterly, 35(1), 83-101.

Trautwein, S., Liberatore, F., Lindenmeier, J., \& von Schnurbein, G. (2020). Satisfaction with informal volunteering during the COVID-19 crisis: An empirical study considering a Swiss online volunteering platform. Nonprofit and Voluntary Sector Quarterly, 0899764020964595

Twenge, J. M. (2013). Does online social media lead to social connection or social disconnection? Journal of College and Character, 14(1), 11-20.

US Census Bureau. (2019). United States Population Growth by Region. Retrieved from https://www. census.gov/popclock/data_tables.php?component=growth. Accessed 7 May 2020.

Valenzuela, S., Park, N., \& Kee, K. F. (2009). Is there social capital in a social network site?: Facebook use and college students' life satisfaction, trust, and participation.

Vossen, H. G., \& Valkenburg, P. M. (2016). Do social media foster or curtail adolescents' empathy? A longitudinal study. Computers in Human Behavior, 63, 118-124.

Warren, A. M., Sulaiman, A., \& Jaafar, N. I. (2015). Understanding civic engagement behaviour on Facebook from a social capital theory perspective. Behaviour \& Information Technology, 34(2), 163-175.

Williams, D. (2006). On and off the'Net: Scales for social capital in an online era. Journal of ComputerMediated Communication, 11(2), 593-628.

Wilson, J. (2000). Volunteering. Annual Review of Sociology, 26(1), 215-240.

Wilson, J., \& Musick, M. (1998). The contribution of social resources to volunteering. Social Science Quarterly, 799-814.

You, L., \& Hon, L. (2019). How social ties contribute to collective actions on social media: A social capital approach. Public Relations Review, 45(4), 101771.

Publisher's note Springer Nature remains neutral with regard to jurisdictional claims in published maps and institutional affiliations. 